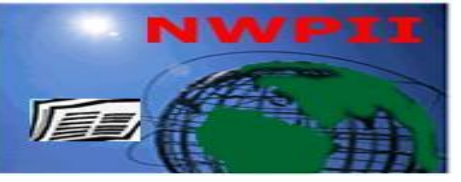

American Journal of Biomedical Sciences

ISSN: 1937-9080

nwpii.com/ajbms.htm

\title{
Bariatric Surgery to Correct Morbid Obesity Also Ameliorates Atherosclerosis in Patients with Type 2 Diabetes Mellitus
}

\author{
Yong Wang and Cuihua Zhang*
}

Departments of Internal Medicine, Medical Pharmacology \& Physiology and Nutritional Sciences, Dalton

Cardiovascular Research Center, University of Missouri, Columbia, MO 65211

*Corresponding Author:

Cuihua Zhang, MD, PhD

Phone: 573-882-2427 (O); 573-884-6208 (Lab)

Fax: 573-884-4232

E-mail address: ZhangCu@missouri.edu

Received: 1 December 2008; | Revised: 15 December 2008; | Accepted: 17 December 2008

\begin{abstract}
Morbid obesity, a physiological dysfunction in humans associated with environmental, genetic and endocrinological origins, has significantly increased in the past few decades in the USA. Many methods have emerged for treating morbid obesity, such as diets, exercise, behavior modification, liposuction, drugs, and surgery; among these, bariatric surgery reduces weight and appears to have other curative effects. Roux-en-Y gastric bypass is the principal form of bariatric surgery, followed by laparoscopic adjustable gastric banding, gastric sleeve operation, duodenojejunal bypass and biliopancreatic diversion. This weight-loss surgery may also affect comorbidities of morbid obesity, such as type 2 diabetes mellitus (T2D), atherosclerosis, hypertension and steatohepatitis. Weight-loss surgery, for example, is associated with a more than $80 \%$ diabetes (data indicates $>80 \%$ ) remission rate in severely obese persons. Empirical evidence also suggests that the use of bariatric surgery reduces atherosclerosis, and may ameliorate other comorbities. This warrants closer examination.
\end{abstract}

Keywords: bariatric surgery, atherosclerosis, morbid obesity, diabetes mellitus

\section{Introduction}

Morbid obesity, particularly in the USA, is becoming a serious health problem. The incidence of obesity in the USA has increased from about $14 \%$ in the 1970 s to $32 \%$ today [1,2]. The latest National Health and Nutrition Examination Surveys show that 127 million individuals are overweight. Of these, 60 million are obese and 810 million have morbid obesity [BMI (body mass index $=$ Body weight/square of height $)>=40$ $\mathrm{kg} / \mathrm{m}^{2}$ ] with serious medical comorbidities resulting in increased disability, morbidity and early mortality [1]. Obesity is now increasing in developing countries in South America, Asia, and Africa, as they adopt the more sedentary and 
affluent lifestyles of developed countries [2].

\section{Potential causes of morbid obesity}

Medically defined, obesity is a physiological dysfunction in humans with environmental, genetic and endocrinological causes [3]. Obesity is characterized by excess body fat accumulation, which is associated with multiple organ-specific pathological consequences [4]. There are many underlying factors that contribute to obesity and morbid obesity. Metabolic disorder is a likely factor leading to morbid obesity. Surplus energy is stored as adipose tissue [5]. Anabolic metabolism in patients with metabolic disorders is much higher than catabolic metabolism. Obesity is becoming endemic, particularly because of an increase in nourishment and a decrease in physical exercise [6].

Some gastrointestinal hormones play important roles in morbid obesity. Peptide YY (PYY) is one such hormone produced by L cells of the distal gastrointestine (GI) [7,8]. PYY is involved in the regulation of GI function by inhibiting gastric acid and pancreatic and intestinal secretions [8,9]. PYY also inhibits gastric emptying (GE) and GI motility [10-12]. PYY has strong anorectic effects and decreases plasma levels of ghrelin [13-15]. Ghrelin is produced in the cells of the gastric fundus [16]. Exogenous ghrelin exhibits potent orexigenic properties when administered peripherally or centrally and also enhances GI motility and GE $[15,17]$. Endogenous ghrelin levels also increase with weight loss and decrease with weight gain $[15,18,19]$. Ghrelin is associated with insulin sensitivity [20,21]. Total ghrelin includes acylated (10\% of total ghrelin) and non-acylated (90\% of total ghrelin) ghrelin, two distinct forms that were previously identified in circulation [20,21]. Furthermore, at pharmacological concentrations, acylated ghrelin increases the degree of insulin resistance, whereas co-administration of acylated ghrelin and nonacylated ghrelin improves insulin sensitivity [22]. Non- acylated ghrelin increased insulin release in vitro by insulinoma cell lines exposed to high glucose concentrations and over-expression of non- acylated ghrelin in pancreatic islets improved the insulin sensitivity to an intraperitoneal glucose load in mice [23-25]. Moreover, when co- administered with acylated ghrelin, non- acylated ghrelin completely prevented the acylated ghrelin induced increase in circulating glucose levels and worsening of insulin sensitivity [26]. Thus, acylated ghrelin and non- acylated ghrelin forms may induce different physiological and/or metabolic effects. Leptin is an adipocyte-derived circulating hormone that provides information to the brain about energy stores [27,28]. The brain's response to leptin involves changes in energy expenditure and food intake [29]. Leptin-deficient mammals, including humans, are markedly hyperphagic, and leptin replacement reverses this [30]. Leptin acts on neural circuits governing food intake to diminish perception of food reward while enhancing the response to satiety signals generated during food consumption.

There are also other gastrointestinal hormones such as cholecystokinin (CCK), glucagons, insulin, corticosteroid and glucagon like peptide 1 (GLP-1) that may play a role in morbid obesity $[31,32]$ via a hormonal feedback loop involved in regulating body weight. The peripheral signals of hormones and vagal inputs from the gut, liver and fat provide information about the current nutritional state of the body. These signals are conveyed to the brainstem and hypothalamus where monoaminergic and peptidergic neurons integrate the information to modulate food intake $[33,34]$.

\section{Co-morbidities associated with morbid obesity}

Obesity and T2D are emerging as the greatest public health problems of the coming decade [35]. The conditions are strongly linked, with the increased prevalence of T2D correlating with the increased prevalence of obesity [36]. Approximately half of those diagnosed with T2D are obese [37]. Early and intensive treatment of T2D is known to improve health and quality of life [35,38-40]. Weight control is the most important kind of T2D management, as weight loss reduces morbidity and mortality [41]. Recent evidence indicates that improvement in blood glucose level is related to degree of weight loss [42].

Insulin resistance refers to a decreased capacity of circulating insulin to regulate nutrient 
metabolism. Individuals with insulin resistance are predisposed to developing $\mathrm{T} 2 \mathrm{D}$, with insulin resistance as an integral feature of its pathophysiology [43,44]. Chronic secretion of large amounts of insulin to overcome tissue insensitivity can lead, in predisposed individuals, to pancreatic $\beta$ cell failure and concomitant defects in glucose and lipid metabolism [45]. Presently, few genetic causes have been identified. Insulin resistance is believed to be promoted by a sedentary lifestyle, obesity, fatty diet and increased age, and reversed by exercise and weight loss.

Overweight and obesity are associated with dyslipidemia, atherosclerosis, hypertension, cancer, osteoarthrosis, etc [46-48].Atherosclerosis involves a complex pathologic process thought to be initiated principally at sites of endothelial dysfunction by the retention, accumulation, and oxidative modification of lipoproteins in the arterial wall, especially the coronary arterial wall [49]. This comorbidity can result in myocardial infarction and sudden death. It accounts for over 500,000 deaths annually in the United States. Diseases related to atherosclerosis such as myocardial infarction and stroke account for the majority of death in industrialized countries. The proportion of mortality caused by cardiovascular complications is 44/2037, which is the major cause of death in obese patients [50,51]. Hypertension and dyslipidaemia often manifest concomitantly with obesity and insulin resistance. The activity of the renin-angiotensin system is elevated in obese patients, and such elevations may enhance vasoconstriction, thereby leading to an increase in blood pressure [52-55].

Accumulation of lipid in the liver often accompanies and parallels weight gain and obesity [56]. Pro-inflammatory substances activate Kupffer cells, which are abundant in the liver and account for over $5 \%$ of total cells. The activation state of Kupffer cells increases with obesity [57]. Additional immune cells in the liver may also be involved in inflammation-induced insulin resistance. Morbid obesity is a type of local or systemic state of pro- or subacute inflammation. Signals such as NF- $\kappa \mathrm{B}, \mathrm{TNF}-\alpha$ and interleukins are found to be elevated in liver [57-62]. Obesity and lack of physical activity have been associated with many kinds of malignant tumors, including pancreatic cancer, colon cancer, breast cancer, prostate cancer and ovarian tumor [63-65]. Tumors are reported to be the major noncardiovascular cause of mortality in obese patients and the mortality proportion of tumor is $48 / 2037$ [50]. Obesity is also associated with many other comorbidities, such as cholelithiasis, gastroesophageal reflux, obstructive sleep apnea, degenerative joint disease, gout, lower back pain, and polycystic ovary syndrome [66,67].

\section{Bariatric surgery: A new method in body weight control}

Many methods are used to treat obesity and morbid obesity, such as diets, exercise, behavior modification, liposuction and drugs [68]. The US Center for Disease Control reports that obesity will increase to $39 \%$ by 2010 , despite current attempts at preventative treatment [69-71]. There is thus an urgent need to address the status, cost and effectiveness of current healthcare options for treating morbid obesity. Three licensed drugsorlistat (Xenical; Hoffman-LaRoche, USA), sibutramine (Meridia; Abbott Laboratories, USA) and rimonabant (Acomplia, France)—require a two year treatment regimen to achieve a 5-10\% weight loss in $60-70 \%$ of obese patients [71]. Combining weight-loss drugs may provide some added benefit as well [69]. Reports show that abdominal liposuction does not significantly improve obesity-associated metabolic abnormalities [68,72]. Furthermore behavior modification and drug therapy in morbidly obese patients are ineffective in inducing major weight loss [70]; this suggests that surgery is the most effective and reliable option for treating the morbidly obese patient $[73,74]$.

Observational evidence suggests that weightloss surgery is associated with a $60 \%$ to $80 \%$ diabetes remission rate in severely obese persons and that earlier interventions are more likely to provide remission [75]. Concerns exist regarding the lack of evidence, as well as the safety, invasiveness, and cost-effectiveness of surgical weight loss procedures. Providing appropriate evidence has previously proved problematic, because the invasive nature of the surgery makes participant recruitment difficult. However, with the advent of safer, less invasive surgical weight- 
loss procedures, randomized trials are now feasible, and it is possible to study the examining mild to moderate obesity, which is responsible for many cases of diabetes.

Of the 180,000-200,000 bariatric surgeries performed in 2006, about $80 \%$ were Roux-en-Y gastric bypass (RYGB). RYGB also reverses and ameliorates the major cardiovascular and metabolic risk factors, including T2D and hyperlipidemia and dyslipidemia. RYGB also reduces long-term mortality and morbidity associated with obesity, and decreases health care costs, although recidivism occurs in about $20 \%$ of patients who fail to sustain their weight loss [55,76-78]. Weight loss as a result of RYGB is probably due to two reasons. First is the small gastric pouch that limits caloric intake. Secondly, Roux-en-Y loop of hindgut short-circuits the remaining gastrointestinal tract, thereby decreasing nutrient absorption. However, evidence suggests that hormonal components play a major role in reducing food intake and decreasing weight after RYGB [78,79]. Other mechanisms are initiated in the creation of the gastric pouch because it divides vagal parasympathetic and sympathetic fibers, thereby influencing the afferent signals to the brain. Efferent signals can also be disrupted, which may play a role in the outcome of this operation [80].

Besides the body weight change, the fasting glucose and insulin resistance are also obviously decreased after bariatric surgery. And these changes come even earlier than weight change [81]. Edward Mason mentioned that gastric bypass was reported to reverse diabetes as far back as the 1950s. After operation, surgeons were aware of the fact that before the patients got out of the hospital, they no longer needed insulin [81]. Bypass surgery decreased fasting glucose to normal level [80]. As research expands, gastric bypass surgeries are beginning to be performed on less obese patients with diabetes although there can be severe complications, such as infection, gallstones and hernias. There's "huge demand, no regulation, everybody's got their own operation. Patients are willing to do whatever it takes to get it." Currently, U.S. National Institutes of Health guidelines recommend that gastric bypass surgery be considered only for people who have a body mass index (BMI) of at least 40. At a meeting in
Rome last year, $78 \%$ of attendees supported lowering the limit to a BMI of 30 for those with diabetes just because T2D contributes to more than1 million deaths worldwide each year $[50,81]$.

However, these mechanisms do not sufficiently account for the maintenance of body weight loss or regain after RYGB. Perhaps the hypothalamus, which regulates GI hormone secretion via efferent vagal and sympathetic fibers to the GI tract and via hypothalamic neuropituitary secretions of hormone precursor, contributes to a decrease of food intake after RYGB [82-84]. Experimental data from both human and rat consistently show resolution of T2D after RYGB. After RYGB, most T2D patients no longer need insulin, even before they have lost much weight. Some patients even suffer from hypoglycemia [81]. The data strongly suggest that a hormonal component(s) plays a contributory role in reducing food intake and in facilitating protracted weight loss after RYGB [85] due to the rearranged anatomy created by the RYGB to provide direct entry of food into the jejunum and hindgut. Food bypasses the remaining neuroendocrine and physiologically functional stomach as well as the duodenum and proximal jejunum, thereby circumventing their hormonal secreting, digestive, and absorptive functions [81]. Several studies have shown a positive association between obesity and an increased rate of death, with an even greater risk of death among persons with a BMI of 35 or more, as compared with those with a BMI of 30 to 34 [51]. Sjöström L and Ted D. Adams compared the mortality of patients who received bariatric surgery in 20 years and summarized the probable reasons for mortality in morbid obese patients [50,51].

Cardiovascular diseases and hypertension are important co-morbidities in morbidly obese patients (19.3/10000), which are believed to be the main contributors to mortality [50]. Cancer $(15 / 10000)$ and diabetes (3.5/10000) are believed to be the other two major reasons for mortality in obese patients. After bariatric surgery, the mortality rate for cardiovascular disease is $8.5 / 10000$, and for cancer and diabetes are $5.4 / 10000$ and $0.3 / 10000$, respectively [50,51]. Bariatric surgery can increase the survival rate in patients whose BMI are larger than $45 \mathrm{~kg} / \mathrm{m}^{2}$. This is reported to be the most effective option for 
weight loss in the severely obese. Obesity is prevalent and associated with multiple medical comorbidities, including early death from heart disease and cancer [51,86]. Weight loss yields improvement of these co-morbidities and decreases mortality $[50,55,76,77]$.

\section{Laparoscopic lap band operation (LAGB)}

Laparoscopic adjustable gastric banding, gastric sleeve operation, duodenojejunal bypass and biliopancreatic diversion are also widely used in the treatment of morbid obesity [87-89]. Gastric fundus and small curve are isolated and one adjustable gastric band is fitted around the uppermost part of the stomach with golden finger, forming a 15cc small pouch [73]. This can be inflated or deflated at any time after the operation and helps the patient continually lose weight until they reach their goals. The restriction takes place in the radiology suite and normally takes 15 minutes. This simple procedure is painless. Saline is injected into a port placed under the skin in the wall of the stomach. A tube connects the band to the port.

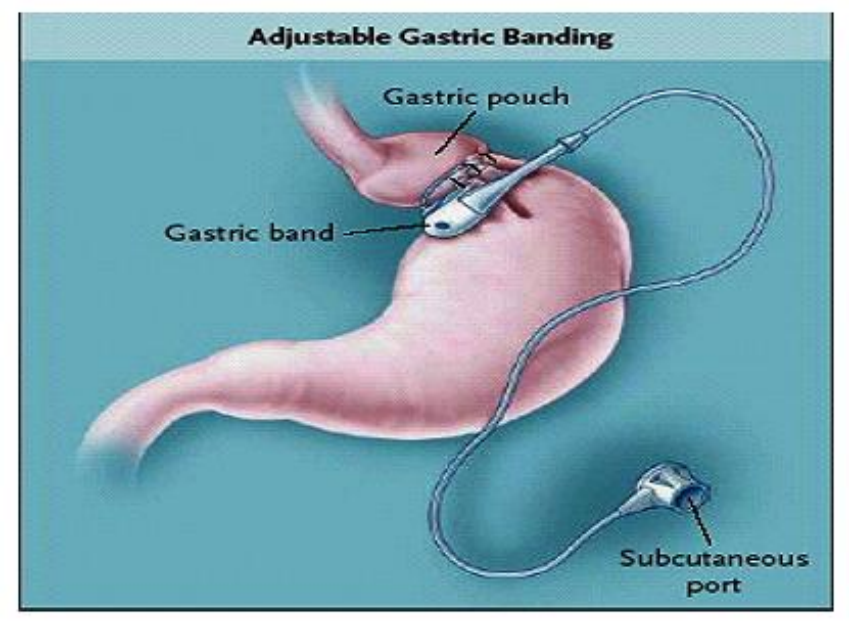

Figure 1. Laparoscopic adjustable lap band surgery is depicted. Adjustable gastric banding is a kind of restrictive bariatric surgery that produces a small pouch at the cardium of the stomach and thus restricts the volume and velocity of food intake. It is much smaller for the first pouch and makes patients feel full quickly while eating. Thus food intake decreases. A lap band is placed around cardium of the stomach and fixed with a suture. The band is connected with a subcutaneous port.
After surgery, saline is injected into the port to decrease the pouch diameter, and thus decrease food intake.

\section{Laparoscopic sleeve gastrectomy (LSG)}

A gastric tube is created using repeated firing with linear staplers from the distal antrum to the Hiss angle, with complete removal of the greater curvature and fundus. During the operation, a gastroscope is maintained in the gastric cavity to prevent a complete closure of the gastric cavity by the linear stapling procedure (Fig. 2).

\section{Laparoscopic gastric bypass}

RYGB, the common bariatric surgery performed in the United States, combines a restrictive and a malabsorptive procédure [51]. A small gastric pouch $(15-30 \mathrm{ml})$ is created to restrict food intake and a Roux-en-Y gastrojejunostomy provides the mild malabsorptive component. Superior weight loss including excellent long-term weight reduction and elimination of co-morbidities occurs in $95 \%$ T2D patients and $80 \%$ of T2D were cured after Roux-en-Y gastric bypass surgery compared to vertical banded gastroplasty2D) [51]. Early and late complication rates are reasonably low, and operative mortality ranges from 0.2 to 1 percent [51] (Fig. 3).

\section{The Biliopancreatic Diversion - Duodenal Switch}

In the Biliopancreatic Diversion-Duodenal switch (BPD/DS), roughly half of the stomach is permanently removed. The stomach goes from the shape of a small pineapple to the size and shape of a banana. The pylorus, which is the valve at the outlet of the stomach, remains intact. The stomach is then connected to the last 250 centimeters ( 8 feet) of small intestine. The remainder of the small intestine is connected 100 centimeters from the end of the small bowel, forming the common channel, where food mixes with the digestive enzymes.

\section{Prospects for bariatric surgery eliminating atherosclerosis in morbid obesity}

Atherosclerosis accounts for over 500,000 deaths annually in the United States [90]. Diseases 


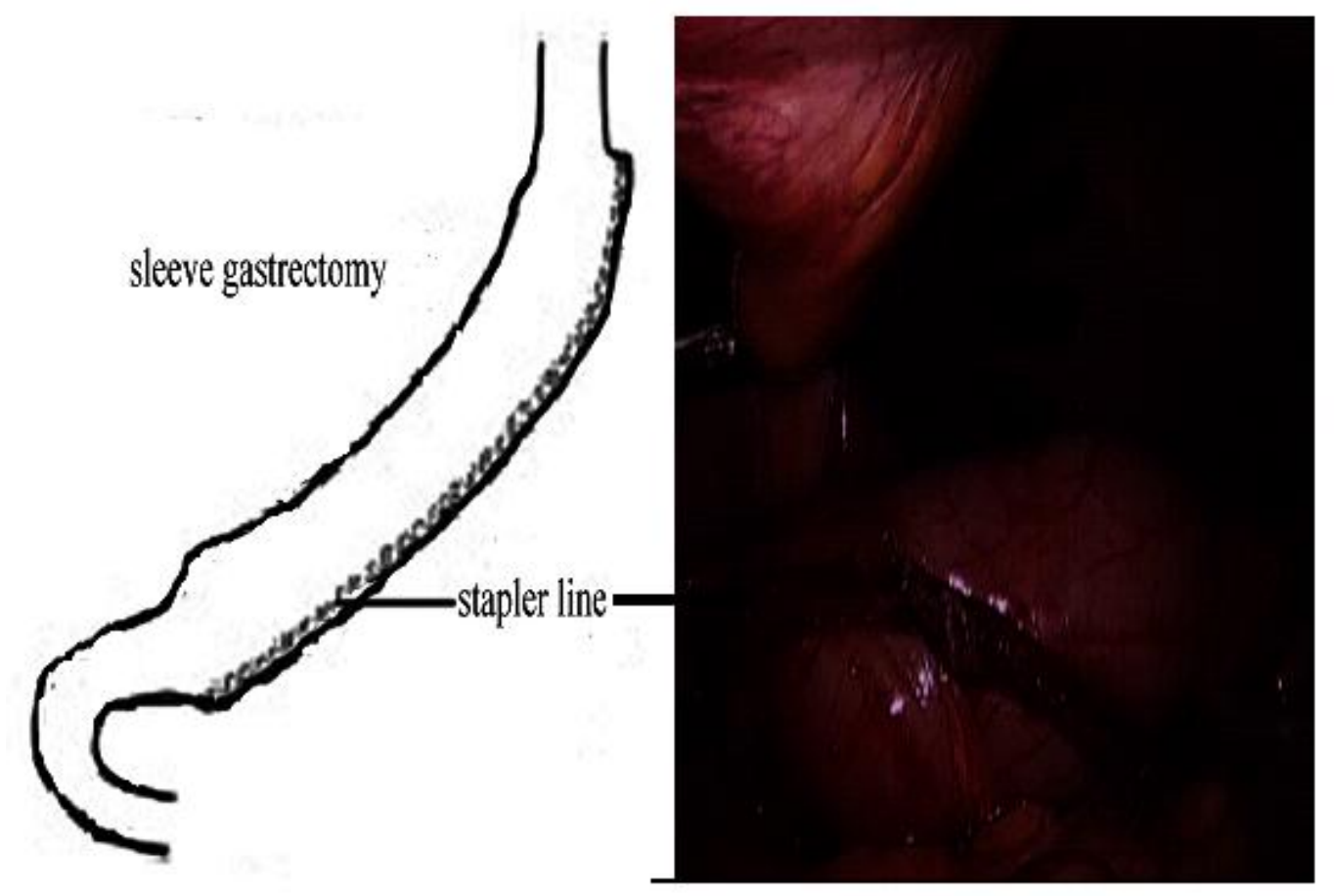

Figure 2. Laparoscopic sleeve gastrectomy is depicted. Sleeve gastrectomy is also a kind of restrictive bariatric surgery. Using a laparoscope, an $80-90 \%$ reduction in the stomach volume is achieved with a liner stapler along the small curve. Initially, the larger omentum is moved away with LigaSure, then the liner staplers are used to reduce all of the larger curve and gastric fundus, leaving about 10-20\% of the stomach in the small curve. In this way, food passes through a smaller volume of the stomach. The serum ghrelin (a major orexigenic hormone in the gastrointestinal tract) level decreases significantly after surgery.

related to atheroscleros such as myocardial infarction and stroke account for the majority of deaths in industrialized countries [91,92]. Atherosclerosis is a complex, multifactorial disease with both genetic and environmental determinants. Despite extensive research, the link between dietary habits, traditional risk factors such as hypertension, smoking, diabetes, and obesity, and the development of atherosclerosis has not been fully elucidated [93]. In some trials on atherosclerosis and hypertension, researchers have found a direct association between the amount of weight loss and blood pressure reduction at 36 months $[92,93]$. Prospective cohort studies have also found that atherosclerosis and hypertension prevalence decreases with weight loss [94-96]. In addition, several researchers have found positive associations between weight gain and obesity with atherosclerosis and hypertension [94,97-100].

Epidemiologic evidence for links between obesity and inflammation have existed for decades, although it has not been detailed in terms of its importance to the pathophysiologic conditions associated with obesity [101,102]. Epidemiologists have found elevations in markers and potential mediators of inflammation, suggesting that low-grade inflammation precedes and predicts the development of atherosclerosis. Proinflammatory cytokines may cause insulin resistance, and anti-inflammatory medications may reverse it, suggesting that inflammation may be directly involved in the pathogenesis of cytokines. Evidence suggests that both macronutrient intake and obesity may activate inflammatory signaling pathways in cells [103]. Glucose and fat intake have both been shown to induce inflammation, potentially through increases in oxidative stress and the activities of transcription factors such as nuclear factor $\mathrm{NF}-\kappa \mathrm{B}$, activating protein-1, and early growth response- 1 $[104,105]$. Intravenous lipid infusion (triglyceride plus heparin) in normal subjects can be used to raise levels of free fatty acids (FFA) to those 
found in obese subjects, which leads to an inflammatory response [106].

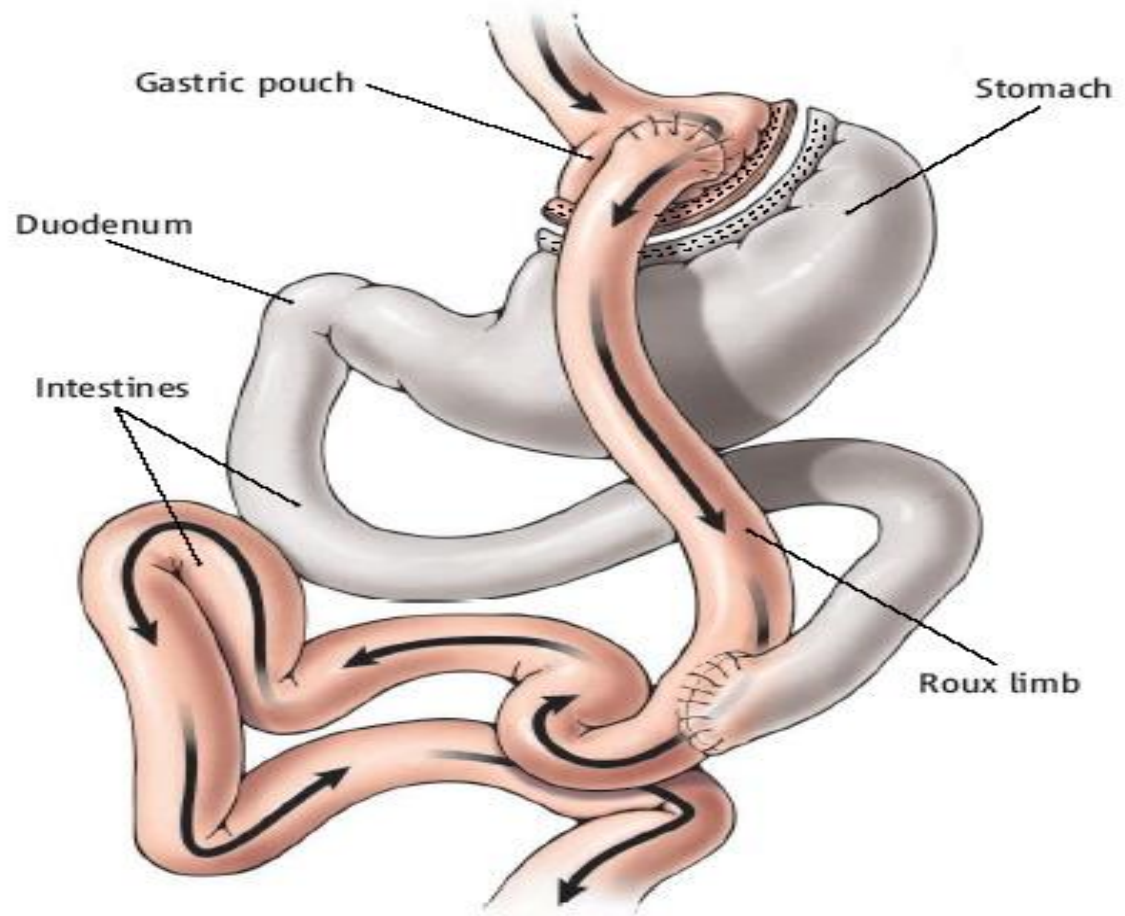

Figure 3. Laparoscopic Roux-en-Y gastric bypass is depicted. Roux-en-Y gastric bypass is the most widely used bariatric surgery in the clinic. The cardium is separated from the major part of the stomach and anastomized with the jejunum. The total volume of the small pouch is about $50 \mathrm{ml}$. The total stomach and duodenum and about 100-150 cm of the jejunum is bypassed. Food passes through the small pouch and goes to the jejunum directly. In this way, the gastric fundus and the duodenum are bypassed. The small intestine is also partly bypassed. As a result, the fasting glucose and insulin resistance decrease to normal right after surgery. Of the 180,000-200,000 bariatric surgeries performed in 2006, about $80 \%$ were Roux-en-Y gastric bypass.

$\mathrm{NF}-\kappa \mathrm{B}$ pathway and c-Jun NH2-terminal kinase (JNK) pathway are activated by many of the same proinflammatory stimuli including cytokines such as TNF- $\alpha$, which in addition to being activators of NF- $\kappa \mathrm{B}$ are also NF- $\kappa \mathrm{B}-$ regulated products. This suggests a potential link between elevated circulating or tissue lipid concentrations and the immune system. Reactive oxygen species, endoplasmic reticulum stress, and ceramides are increased by adiposity, and all have been shown to activate both JNK and NF- $\kappa \mathrm{B}$. As previously mentioned, circulating ghrelin participates in long-term regulation of body weight, its plasma level increases with weight loss as part of the compensatory response to an energy deficit [20,107,108]. Recently, ghrelin and its receptors were detected in cardiovascular tissues, indicating that the peptide may play a role in cardiovascular regulation [109]. Stimulation of growth hormone secretagogue receptor(GHSR) has been shown to prevent cardiac damage after ischemia/reperfusion in hypophysectomized rats [110]. Moreover, administration of ghrelin improved left ventricular function and attenuated the development of cardiac cachexia in a heart failure model [111]. Furthermore, ghrelin improved mortality and corrected the hemodynamic and metabolic abnormalities associated with endotoxic shock in rats [112]. The endocrine activity of ghrelin is dependent on its acylation and subsequent interaction with GHSR1a [20]. However, both ghrelin and des-acyl ghrelin inhibit apoptosis in cardiomyocytes and endothelial cells, suggesting that ghrelin may also act through a novel, yet to be identified receptor, which is distinct from GHSR-1a [113]. Some 
reports show that ghrelin inhibits basal and TNF- $\alpha$ induced chemotactic cytokine production and mononuclear cell adhesion in human vascular endothelial cells [109]. In contrast, gastric bypass may disrupt ghrelin secretion by isolating ghrelinproducing cells from direct contact with ingested nutrients, which normally regulate ghrelin levels, and this effect may contribute to the efficacy of the procedure in reducing weight $[18,107,114-$ 116].

\section{Concluding Remarks}

Morbid obesity and T2D mellitus are major contributors to the morbidity and mortality in our society. The percentage of patients with these diseases is rising rapidly and now is even affecting the very young. Cardiovascular comorbidities, such as myocardial infarction, hypertension, heart failure and so on, are the major reasons for mortality. Cancer is another major contributor, along with other complications, such as hyperlipidemia, steatohepatitis and renal dysfunction. Bariatric surgery controls comorbidities and decreases the mortality rate for the morbidly obese better than other methods, Bariatric surgeries, especially gastric bypass, are

\section{References}

1 Guijarro A, Kirchner $H$, Meguid MM: Catabolic effects of gastric bypass in a dietinduced obese rat model. Curr Opin Clin Nutr Metab Care 2006;9:423-435.

2 Zimmet P, Alberti KG, Shaw J: Global and societal implications of the diabetes epidemic. Nature 2001;414:782-787.

3 Suzuki S, Ramos EJ, Goncalves CG, Chen C, Meguid MM: Changes in gi hormones and their effect on gastric emptying and transit times after roux-en-y gastric bypass in rat model. Surgery 2005;138:283-290.

$4 \mathrm{Xu} \mathrm{Y,} \mathrm{Ramos} \mathrm{EJ,} \mathrm{Middleton} \mathrm{F,} \mathrm{Romanova} \mathrm{I,}$ Quinn R, Chen C, Das U, Inui A, Meguid MM: Gene expression profiles post roux-en-y gastric bypass. Surgery 2004;136:246-252.

5 Haslam DW, James WP: Obesity. Lancet 2005;366:1197-1209. proven to decrease fasting glucose and insulin resistance right after surgery. More and more surgeons are using this kind of technique in treating obese patients. Some others even use this technique in treating diabetes patients with or without obesity. While the modes of action are not completely understood at present, especially regarding effects in treating cardiovascular comorbidities, cancer and so on, current results are promising and further research is warranted. Gastric bypass surgery appears to have significant increased therapeutic potential for treating morbid obesity and T2D.

\section{Funding Sources}

This study was supported by grants from Pfizer Atorvastatin Research Award (2004-37), American Heart Association Scientist Development Grant (110350047A) and NIH grant (RO1-HL077566) to Dr. Cuihua Zhang.

\section{Acknowledgements}

The paper has been revised by Paul J Fadel. All authors thank him very much for his hard work.

6 Mokdad AH, Bowman BA, Ford ES, Vinicor F, Marks JS, Koplan JP: The continuing epidemics of obesity and diabetes in the united states. Jama 2001;286:1195-1200.

7 Batterham RL, Bloom SR: The gut hormone peptide yy regulates appetite. Ann N Y Acad Sci 2003;994:162-168.

8 Batterham RL, ffytche DH, Rosenthal JM, Zelaya FO, Barker GJ, Withers DJ, Williams SC: Pyy modulation of cortical and hypothalamic brain areas predicts feeding behaviour in humans. Nature 2007;450:106109.

9 Grill HJ, Skibicka KP, Hayes MR: Imaging obesity: Fmri, food reward, and feeding. Cell Metab 2007;6:423-425.

10 Allen JM, Fitzpatrick ML, Yeats JC, Darcy K, Adrian TE, Bloom SR: Effects of peptide yy and neuropeptide $\mathrm{y}$ on gastric emptying in man. Digestion 1984;30:255-262. 
11 Pappas TN, Debas HT, Goto Y, Taylor IL: Peptide yy inhibits meal-stimulated pancreatic and gastric secretion. Am J Physiol 1985;248:G118-123.

12 Savage AP, Adrian TE, Carolan G, Chatterjee VK, Bloom SR: Effects of peptide yy (pyy) on mouth to caecum intestinal transit time and on the rate of gastric emptying in healthy volunteers. Gut 1987;28:166-170.

13 Batterham RL, Cohen MA, Ellis SM, Le Roux CW, Withers DJ, Frost GS, Ghatei MA, Bloom SR: Inhibition of food intake in obese subjects by peptide yy3-36. N Engl J Med 2003;349:941-948.

14 Pittner RA, Moore CX, Bhavsar SP, Gedulin BR, Smith PA, Jodka CM, Parkes DG, Paterniti JR, Srivastava VP, Young AA: Effects of pyy[3-36] in rodent models of diabetes and obesity. Int J Obes Relat Metab Disord 2004;28:963-971.

15 Asakawa A, Inui A, Kaga T, Yuzuriha H, Nagata T, Ueno N, Makino S, Fujimiya $M$, Niijima A, Fujino MA, Kasuga M: Ghrelin is an appetite-stimulatory signal from stomach with structural resemblance to motilin. Gastroenterology 2001;120:337-345.

16 Date Y, Kojima M, Hosoda H, Sawaguchi A, Mondal MS, Suganuma T, Matsukura S, Kangawa K, Nakazato M: Ghrelin, a novel growth hormone-releasing acylated peptide, is synthesized in a distinct endocrine cell type in the gastrointestinal tracts of rats and humans. Endocrinology 2000;141:4255-4261.

17 Fukuda H, Mizuta Y, Isomoto H, Takeshima F, Ohnita K, Ohba K, Omagari K, Taniyama K, Kohno S: Ghrelin enhances gastric motility through direct stimulation of intrinsic neural pathways and capsaicin-sensitive afferent neurones in rats. Scand J Gastroenterol 2004;39:1209-1214.

18 Tschop M, Smiley DL, Heiman ML: Ghrelin induces adiposity in rodents. Nature 2000;407:908-913.

19 Nakazato M, Murakami N, Date Y, Kojima M, Matsuo H, Kangawa K, Matsukura S: A role for ghrelin in the central regulation of feeding. Nature 2001;409:194-198.

20 Kojima M, Hosoda H, Date Y, Nakazato M, Matsuo H, Kangawa K: Ghrelin is a growth- hormone-releasing acylated peptide from stomach. Nature 1999;402:656-660.

21 Kojima M, Kangawa K: Structure and function of ghrelin. Results Probl Cell Differ 2008;46:89-115.

22 Gauna C, Delhanty PJ, Hofland LJ, Janssen JA, Broglio F, Ross RJ, Ghigo E, van der Lely AJ: Ghrelin stimulates, whereas des-octanoyl ghrelin inhibits, glucose output by primary hepatocytes. J Clin Endocrinol Metab 2005;90:1055-1060.

23 Gauna C, Delhanty PJ, van Aken MO, Janssen JA, Themmen AP, Hofland LJ, Culler M, Broglio F, Ghigo E, van der Lely AJ: Unacylated ghrelin is active on the ins-1e rat insulinoma cell line independently of the growth hormone secretagogue receptor type 1a and the corticotropin releasing factor 2 receptor. Mol Cell Endocrinol 2006;251:103111.

24 Granata R, Settanni F, Biancone L, Trovato L, Nano R, Bertuzzi F, Destefanis S, Annunziata M, Martinetti M, Catapano F, Ghe C, Isgaard J, Papotti M, Ghigo E, Muccioli G: Acylated and unacylated ghrelin promote proliferation and inhibit apoptosis of pancreatic beta-cells and human islets: Involvement of 3',5'-cyclic adenosine monophosphate/protein kinase a, extracellular signal-regulated kinase $1 / 2$, and phosphatidyl inositol 3-kinase/akt signaling. Endocrinology 2007;148:512-529.

25 Iwakura H, Hosoda K, Son C, Fujikura J, Tomita T, Noguchi M, Ariyasu H, Takaya K, Masuzaki H, Ogawa Y, Hayashi T, Inoue G, Akamizu T, Hosoda H, Kojima M, Itoh $\mathrm{H}$, Toyokuni S, Kangawa K, Nakao K: Analysis of rat insulin ii promoter-ghrelin transgenic mice and rat glucagon promoter-ghrelin transgenic mice. J Biol Chem 2005;280:15247-15256.

26 Heijboer AC, van den Hoek AM, Parlevliet ET, Havekes LM, Romijn JA, Pijl H, Corssmit EP: Ghrelin differentially affects hepatic and peripheral insulin sensitivity in mice. Diabetologia 2006;49:732-738.

27 Morton GJ, Cummings DE, Baskin DG, Barsh GS, Schwartz MW: Central nervous system control of food intake and body weight. Nature 2006;443:289-295. 
28 Pinto S, Roseberry AG, Liu H, Diano S, Shanabrough M, Cai X, Friedman JM, Horvath TL: Rapid rewiring of arcuate nucleus feeding circuits by leptin. Science 2004;304:110-115.

29 Elmquist JK, Flier JS: Neuroscience. The fatbrain axis enters a new dimension. Science 2004;304:63-64.

30 Farooqi IS, Bullmore E, Keogh J, Gillard J, O'Rahilly S, Fletcher PC: Leptin regulates striatal regions and human eating behavior. Science 2007;317:1355.

31 Chandra R, Liddle RA: Cholecystokinin. Curr Opin Endocrinol Diabetes Obes 2007;14:6367.

32 Rodieux F, Giusti V, D'Alessio DA, Suter M, Tappy L: Effects of gastric bypass and gastric banding on glucose kinetics and gut hormone release. Obesity (Silver Spring) 2008;16:298305.

33 Inui A: Feeding and body-weight regulation by hypothalamic neuropeptides--mediation of the actions of leptin. Trends Neurosci 1999;22:6267.

34 Schwartz MW, Woods SC, Porte D, Jr., Seeley RJ, Baskin DG: Central nervous system control of food intake. Nature 2000;404:661671 .

35 Tight blood pressure control and risk of macrovascular and microvascular complications in type 2 diabetes: Ukpds 38. Uk prospective diabetes study group. Bmj 1998;317:703-713.

36 Mokdad AH, Ford ES, Bowman BA, Nelson DE, Engelgau MM, Vinicor F, Marks JS: Diabetes trends in the u.S.: 1990-1998. Diabetes Care 2000;23:1278-1283.

37 Leibson CL, Williamson DF, Melton LJ, 3rd, Palumbo PJ, Smith SA, Ransom JE, Schilling PL, Narayan KM: Temporal trends in bmi among adults with diabetes. Diabetes Care 2001;24:1584-1589.

38 U.K. Prospective diabetes study 16. Overview of 6 years' therapy of type ii diabetes: A progressive disease. U.K. Prospective diabetes study group. Diabetes 1995;44:1249-1258.

39 Intensive blood-glucose control with sulphonylureas or insulin compared with conventional treatment and risk of complications in patients with type 2 diabetes (ukpds 33). Uk prospective diabetes study (ukpds) group. Lancet 1998;352:837-853.

40 Quality of life in type 2 diabetic patients is affected by complications but not by intensive policies to improve blood glucose or blood pressure control (ukpds 37). U.K. Prospective diabetes study group. Diabetes Care 1999;22:1125-1136.

41 Williamson DF, Thompson TJ, Thun M, Flanders D, Pamuk E, Byers T: Intentional weight loss and mortality among overweight individuals with diabetes. Diabetes Care 2000;23:1499-1504.

42 Norris SL, Zhang X, Avenell A, Gregg E, Bowman B, Serdula M, Brown TJ, Schmid $\mathrm{CH}$, Lau J: Long-term effectiveness of lifestyle and behavioral weight loss interventions in adults with type 2 diabetes: A meta-analysis. Am J Med 2004;117:762-774.

43 Saltiel AR, Kahn CR: Insulin signalling and the regulation of glucose and lipid metabolism. Nature 2001;414:799-806.

44 Petersen KF, Dufour S, Befroy D, Garcia R, Shulman GI: Impaired mitochondrial activity in the insulin-resistant offspring of patients with type 2 diabetes. $N$ Engl J Med 2004;350:664-671.

45 Yuan M, Konstantopoulos N, Lee J, Hansen L, Li ZW, Karin M, Shoelson SE: Reversal of obesity- and diet-induced insulin resistance with salicylates or targeted disruption of ikkbeta. Science 2001;293:1673-1677.

46 Lazar MA: How obesity causes diabetes: Not a tall tale. Science 2005;307:373-375.

47 Brolin RE: Bariatric surgery and long-term control of morbid obesity. Jama 2002;288:2793-2796.

48 O'Brien PE, Dixon JB: The extent of the problem of obesity. Am J Surg 2002;184:4S$8 \mathrm{~S}$.

49 Chapman MJ, Sposito AC: Hypertension and dyslipidaemia in obesity and insulin resistance: Pathophysiology, impact on atherosclerotic disease and pharmacotherapy. Pharmacol Ther 2008;117:354-373.

50 Sjostrom L, Narbro K, Sjostrom CD, Karason K, Larsson B, Wedel H, Lystig T, Sullivan M, Bouchard C, Carlsson B, Bengtsson C, 
Dahlgren S, Gummesson A, Jacobson P, Karlsson J, Lindroos AK, Lonroth H, Naslund I, Olbers T, Stenlof K, Torgerson J, Agren G, Carlsson LM: Effects of bariatric surgery on mortality in swedish obese subjects. N Engl J Med 2007;357:741-752.

51 Adams TD, Gress RE, Smith SC, Halverson RC, Simper SC, Rosamond WD, Lamonte MJ, Stroup AM, Hunt SC: Long-term mortality after gastric bypass surgery. N Engl J Med 2007;357:753-761.

52 Barton M, Carmona R, Ortmann J, Krieger JE, Traupe T: Obesity-associated activation of angiotensin and endothelin in the cardiovascular system. Int J Biochem Cell Biol 2003;35:826-837.

53 Rahmouni K, Mark AL, Haynes WG, Sigmund CD: Adipose depot-specific modulation of angiotensinogen gene expression in diet-induced obesity. Am J Physiol Endocrinol Metab 2004;286:E891895.

54 Rahmouni K, Correia ML, Haynes WG, Mark AL: Obesity-associated hypertension: New insights into mechanisms. Hypertension 2005;45:9-14.

55 Buchwald H, Avidor Y, Braunwald E, Jensen MD, Pories W, Fahrbach K, Schoelles K: Bariatric surgery: A systematic review and meta-analysis. Jama 2004;292:1724-1737.

56 Arun J, Jhala N, Lazenby AJ, Clements R, Abrams GA: Influence of liver biopsy heterogeneity and diagnosis of nonalcoholic steatohepatitis in subjects undergoing gastric bypass. Obes Surg 2007;17:155-161.

57 Cai D, Yuan M, Frantz DF, Melendez PA, Hansen L, Lee J, Shoelson SE: Local and systemic insulin resistance resulting from hepatic activation of ikk-beta and nf-kappab. Nat Med 2005;11:183-190.

58 Guebre-Xabier M, Yang S, Lin HZ, Schwenk R, Krzych U, Diehl AM: Altered hepatic lymphocyte subpopulations in obesity-related murine fatty livers: Potential mechanism for sensitization to liver damage. Hepatology 2000;31:633-640.

59 Li Z, Soloski MJ, Diehl AM: Dietary factors alter hepatic innate immune system in mice with nonalcoholic fatty liver disease. Hepatology 2005;42:880-885.

60 Godfrey DI, Kronenberg M: Going both ways: Immune regulation via cd1d-dependent nkt cells. J Clin Invest 2004;114:1379-1388.

61 Elinav E, Pappo O, Sklair-Levy M, Margalit M, Shibolet O, Gomori M, Alper R, Thalenfeld B, Engelhardt D, Rabbani E, Ilan $\mathrm{Y}$ : Adoptive transfer of regulatory nkt lymphocytes ameliorates non-alcoholic steatohepatitis and glucose intolerance in $\mathrm{ob} / \mathrm{ob}$ mice and is associated with intrahepatic cd8 trapping. J Pathol 2006;209:121-128.

62 Arkan MC, Hevener AL, Greten FR, Maeda S, Li ZW, Long JM, Wynshaw-Boris A, Poli G, Olefsky J, Karin M: Ikk-beta links inflammation to obesity-induced insulin resistance. Nat Med 2005;11:191-198.

63 Davies BJ, Walsh TJ, Ross PL, Knight SJ, Sadetsky N, Carroll PR, Kane CJ: Effect of bmi on primary treatment of prostate cancer. Urology 2008.

64 Drew JE, Farquharson AJ, Padidar S, Duthie GG, Mercer JG, Arthur JR, Morrice PC, Barrera LN: Insulin, leptin, and adiponectin receptors in colon: Regulation relative to differing body adiposity independent of diet and in response to dimethylhydrazine. Am $\mathbf{J}$ Physiol Gastrointest Liver Physiol 2007;293:G682-691.

65 Slattery ML, Curtin K, Sweeney C, Wolff RK, Baumgartner RN, Baumgartner KB, Giuliano AR, Byers T: Modifying effects of il-6 polymorphisms on body size-associated breast cancer risk. Obesity (Silver Spring) 2008;16:339-347.

66 Sise A, Friedenberg FK: A comprehensive review of gastroesophageal reflux disease and obesity. Obes Rev 2008;9:194-203.

67 Stanley T, Misra M: Polycystic ovary syndrome in obese adolescents. Curr Opin Endocrinol Diabetes Obes 2008;15:30-36.

68 Klein S, Fontana L, Young VL, Coggan AR, Kilo C, Patterson BW, Mohammed BS: Absence of an effect of liposuction on insulin action and risk factors for coronary heart disease. N Engl J Med 2004;350:2549-2557. 
69 Hill JO, Wyatt HR, Reed GW, Peters JC: Obesity and the environment: Where do we go from here? Science 2003;299:853-855.

70 Flegal KM, Carroll MD, Ogden CL, Johnson CL: Prevalence and trends in obesity among us adults, 1999-2000. Jama 2002;288:1723-1727.

71 Kirchner H, Guijarro A, Meguid MM: Is a model useful in exploring the catabolic mechanisms of weight loss after gastric bypass in humans? Curr Opin Clin Nutr Metab Care 2007;10:463-474.

72 Kelley DE: Thermodynamics, liposuction, and metabolism. N Engl J Med 2004;350:25422544.

73 Steinbrook R: Surgery for severe obesity. N Engl J Med 2004;350:1075-1079.

74 Pinkney JH, Sjostrom CD, Gale EA: Should surgeons treat diabetes in severely obese people? Lancet 2001;357:1357-1359.

75 Dixon JB, Pories WJ, O'Brien PE, Schauer PR, Zimmet P: Surgery as an effective early intervention for diabesity: Why the reluctance? Diabetes Care 2005;28:472-474.

76 Sjostrom L, Lindroos AK, Peltonen M, Torgerson J, Bouchard C, Carlsson B, Dahlgren S, Larsson B, Narbro K, Sjostrom CD, Sullivan M, Wedel H: Lifestyle, diabetes, and cardiovascular risk factors 10 years after bariatric surgery. N Engl J Med 2004;351:2683-2693.

77 Christou NV, Sampalis JS, Liberman M, Look D, Auger S, McLean AP, MacLean LD: Surgery decreases long-term mortality, morbidity, and health care use in morbidly obese patients. Ann Surg 2004;240:416-423; discussion 423-414.

78 Borg CM, le Roux CW, Ghatei MA, Bloom SR, Patel AG, Aylwin SJ: Progressive rise in gut hormone levels after roux-en-y gastric bypass suggests gut adaptation and explains altered satiety. Br J Surg 2006;93:210-215.

79 Cummings DE, Overduin J, Foster-Schubert KE: Gastric bypass for obesity: Mechanisms of weight loss and diabetes resolution. J Clin Endocrinol Metab 2004;89:2608-2615.

80 Phillips RJ, Powley TL: Plasticity of vagal afferents at the site of an incision in the wall of the stomach. Auton Neurosci 2005;123:44-53.
81 Couzin J: Medicine. Bypassing medicine to treat diabetes. Science 2008;320:438-440.

82 Grill HJ, Kaplan JM: The neuroanatomical axis for control of energy balance. Front Neuroendocrinol 2002;23:2-40.

83 Middleton FA, Ramos EJ, Xu Y, Diab H, Zhao $\mathrm{X}$, Das UN, Meguid M: Application of genomic technologies: DNA microarrays and metabolic profiling of obesity in the hypothalamus and in subcutaneous fat. Nutrition 2004;20:14-25.

84 Romanova IV, Ramos EJ, Xu Y, Quinn R, Chen C, George ZM, Inui A, Das U, Meguid MM: Neurobiologic changes in the hypothalamus associated with weight loss after gastric bypass. J Am Coll Surg 2004;199:887895.

85 Pories WJ, Swanson MS, MacDonald KG, Long SB, Morris PG, Brown BM, Barakat HA, deRamon RA, Israel G, Dolezal JM, et al.: Who would have thought it? An operation proves to be the most effective therapy for adult-onset diabetes mellitus. Ann Surg 1995;222:339-350; discussion 350-332.

86 Calle EE, Rodriguez C, Walker-Thurmond K, Thun MJ: Overweight, obesity, and mortality from cancer in a prospectively studied cohort of u.S. Adults. N Engl J Med 2003;348:16251638.

87 Dixon JB, O'Brien PE, Playfair J, Chapman L, Schachter LM, Skinner S, Proietto J, Bailey M, Anderson M: Adjustable gastric banding and conventional therapy for type 2 diabetes: A randomized controlled trial. Jama 2008;299:316-323.

88 O'Brien PE, Dixon JB, Laurie C, Skinner S, Proietto J, McNeil J, Strauss B, Marks S, Schachter L, Chapman L, Anderson M: Treatment of mild to moderate obesity with laparoscopic adjustable gastric banding or an intensive medical program: A randomized trial. Ann Intern Med 2006;144:625-633.

89 Parikh M, Ayoung-Chee P, Romanos E, Lewis N, Pachter HL, Fielding G, Ren C: Comparison of rates of resolution of diabetes mellitus after gastric banding, gastric bypass, and biliopancreatic diversion. J Am Coll Surg 2007;205:631-635. 
90 Ross R: The pathogenesis of atherosclerosis: A perspective for the 1990s. Nature 1993;362:801-809.

91 Zyriax BC, Algenstaedt P, Hess UF, Schoffauer $\mathrm{M}$, Bamberger $\mathrm{C}$, Boeing $\mathrm{H}$, Windler E: Factors contributing to the risk of cardiovascular disease reflected by plasma adiponectin: Data from the coronary risk factors for atherosclerosis in women (cora) study. Atherosclerosis 2008;200:403-409.

92 Truesdale KP, Stevens J, Cai J: Effect of 3year weight history on blood pressure: The atherosclerosis risk in communities study. Obesity (Silver Spring) 2008;16:1112-1119.

93 Stevens VJ, Obarzanek E, Cook NR, Lee IM, Appel LJ, Smith West D, Milas NC, MattfeldtBeman M, Belden L, Bragg C, Millstone M, Raczynski J, Brewer A, Singh B, Cohen J: Long-term weight loss and changes in blood pressure: Results of the trials of hypertension prevention, phase ii. Ann Intern Med 2001;134:1-11.

94 Droyvold WB, Midthjell K, Nilsen TI, Holmen J: Change in body mass index and its impact on blood pressure: A prospective population study. Int $\mathrm{J}$ Obes (Lond) 2005;29:650-655.

95 Moore LL, Visioni AJ, Qureshi MM, Bradlee ML, Ellison RC, D'Agostino R: Weight loss in overweight adults and the long-term risk of hypertension: The framingham study. Arch Intern Med 2005;165:1298-1303.

96 Huang Z, Willett WC, Manson JE, Rosner B, Stampfer MJ, Speizer FE, Colditz GA: Body weight, weight change, and risk for hypertension in women. Ann Intern Med 1998;128:81-88.

97 Clinical guidelines on the identification, evaluation, and treatment of overweight and obesity in adults--the evidence report. National institutes of health. Obes Res 1998;6 Suppl 2:51S-209S.

98 Juhaeri, Stevens J, Chambless LE, Tyroler HA, Rosamond W, Nieto FJ, Schreiner P, Jones DW, Arnett D: Associations between weight gain and incident hypertension in a biethnic cohort: The atherosclerosis risk in communities study. Int $\mathbf{J}$ Obes Relat Metab Disord 2002;26:58-64.
99 Field AE, Byers T, Hunter DJ, Laird NM, Manson JE, Williamson DF, Willett WC, Colditz GA: Weight cycling, weight gain, and risk of hypertension in women. Am J Epidemiol 1999;150:573-579.

100 French SA, Jeffery RW, Folsom AR, McGovern P, Williamson DF: Weight loss maintenance in young adulthood: Prevalence and correlations with health behavior and disease in a population-based sample of women aged 55-69 years. Int J Obes Relat Metab Disord 1996;20:303-310.

101 Dandona P, Aljada A, Bandyopadhyay A: Inflammation: The link between insulin resistance, obesity and diabetes. Trends Immunol 2004;25:4-7.

102 Mohanty P, Ghanim H, Hamouda W, Aljada A, Garg R, Dandona P: Both lipid and protein intakes stimulate increased generation of reactive oxygen species by polymorphonuclear leukocytes and mononuclear cells. Am J Clin Nutr 2002;75:767-772.

103 Shoelson SE, Herrero L, Naaz A: Obesity, inflammation, and insulin resistance. Gastroenterology 2007;132:2169-2180.

104 Dhindsa S, Tripathy D, Mohanty P, Ghanim H, Syed T, Aljada A, Dandona P: Differential effects of glucose and alcohol on reactive oxygen species generation and intranuclear nuclear factor-kappab in mononuclear cells. Metabolism 2004;53:330-334.

105 Aljada A, Ghanim H, Mohanty P, Syed T, Bandyopadhyay A, Dandona P: Glucose intake induces an increase in activator protein 1 and early growth response 1 binding activities, in the expression of tissue factor and matrix metalloproteinase in mononuclear cells, and in plasma tissue factor and matrix metalloproteinase concentrations. Am J Clin Nutr 2004;80:51-57.

106 Tripathy D, Mohanty P, Dhindsa S, Syed T, Ghanim H, Aljada A, Dandona P: Elevation of free fatty acids induces inflammation and impairs vascular reactivity in healthy subjects. Diabetes 2003;52:2882-2887.

107 Flier JS, Maratos-Flier E: The stomach speaks--ghrelin and weight regulation. N Engl J Med 2002;346:1662-1663. 
108 Nogueiras R, Tschop M: Biomedicine. Separation of conjoined hormones yields appetite rivals. Science 2005;310:985-986.

$109 \mathrm{Li}$ WG, Gavrila D, Liu X, Wang L, Gunnlaugsson S, Stoll LL, McCormick ML, Sigmund CD, Tang C, Weintraub NL: Ghrelin inhibits proinflammatory responses and nuclear factor-kappab activation in human endothelial cells. Circulation 2004;109:22212226.

110 Locatelli V, Rossoni G, Schweiger F, Torsello A, De Gennaro Colonna V, Bernareggi M, Deghenghi R, Muller EE, Berti F: Growth hormone-independent cardioprotective effects of hexarelin in the rat. Endocrinology 1999; 140:4024-4031.

111 Nagaya N, Uematsu M, Kojima M, Date Y, Nakazato M, Okumura H, Hosoda H, Shimizu W, Yamagishi M, Oya H, Koh H, Yutani C, Kangawa K: Elevated circulating level of ghrelin in cachexia associated with chronic heart failure: Relationships between ghrelin and anabolic/catabolic factors. Circulation 2001;104:2034-2038.

112 Chang L, Zhao J, Yang J, Zhang Z, Du J, Tang C: Therapeutic effects of ghrelin on endotoxic shock in rats. Eur J Pharmacol 2003;473:171-176.
113 Baldanzi G, Filigheddu N, Cutrupi S, Catapano F, Bonissoni S, Fubini A, Malan D, Baj G, Granata R, Broglio F, Papotti M, Surico $\mathrm{N}$, Bussolino $\mathrm{F}$, Isgaard $\mathrm{J}$, Deghenghi $\mathrm{R}$, Sinigaglia F, Prat M, Muccioli G, Ghigo E, Graziani A: Ghrelin and des-acyl ghrelin inhibit cell death in cardiomyocytes and endothelial cells through erk1/2 and pi 3kinase/akt. J Cell Biol 2002;159:1029-1037.

114 Cummings DE, Clement K, Purnell JQ, Vaisse C, Foster KE, Frayo RS, Schwartz MW, Basdevant A, Weigle DS: Elevated plasma ghrelin levels in prader willi syndrome. Nat Med 2002;8:643-644.

115 Cummings DE, Weigle DS, Frayo RS, Breen PA, Ma MK, Dellinger EP, Purnell JQ: Plasma ghrelin levels after diet-induced weight loss or gastric bypass surgery. $\mathrm{N}$ Engl $\mathrm{J}$ Med 2002;346:1623-1630.

116 Cummings DE, Purnell JQ, Frayo RS, Schmidova K, Wisse BE, Weigle DS: A preprandial rise in plasma ghrelin levels suggests a role in meal initiation in humans. Diabetes 2001;50:1714-1719. 